\title{
Tumor necrosis as a prognostic variable for the clinical outcome in patients with renal cell carcinoma: a systematic review and meta-analysis
}

\author{
Lijin Zhang ${ }^{1}$, Zhenlei Zha ${ }^{1+}$, Wei Qu ${ }^{2 \dagger}$, Hu Zhao ${ }^{1 \dagger}$, Jun Yuan ${ }^{1}$, Yejun Feng ${ }^{1}$ and Bin Wu${ }^{1 *}$
}

\begin{abstract}
Background: Tumor necrosis (TN) correlates with adverse outcomes in numerous solid tumors. However, its prognostic value in renal cell carcinoma (RCC) remains unclear. In this study, we performed a meta-analysis to evaluate associations between TN and cancer-specific survival (CSS), overall survival (OS), recurrence-free survival (RFS) and progression-free-survival (PFS) in RCC.

Methods: Electronic searches in PubMed, EMBASE and Web of Science were conducted according to the PRISMA statement. Hazard ratios (HRs) and 95\% confidence intervals (95\% Cls) were calculated to evaluate relationships between TN and RCC. A fixed- or random-effects model was used to calculate pooled HRs and 95\%Cls according to heterogeneity.

Results: A total of 34 cohort studies met the eligibility criteria of this meta-analysis. The results showed that TN was significantly predictive of poorer CSS ( $H R=1.37,95 \% \mathrm{Cl}: 1.23-1.53, p<0.001)$, OS ( $\mathrm{HR}=1.29,95 \% \mathrm{Cl}: 1.20-1.40, p<0.001)$, RFS (HR $=1.55,95 \% \mathrm{Cl}: 1.39-1.72, p<0.001)$ and PFS (HR=1.31,95\% Cl: 1.17-1.46, $p<0.001)$ in patients with RCC. All the findings were robust when stratified by geographical region, pathological type, staging system, number of patients, and median follow-up.
\end{abstract}

Conclusions: The present study suggests that TN is associated with CSS, OS, RFS and PFS clinical outcomes of RCC patients and may serve as a predictor of poor prognosis in these patients.

Keywords: Renal cell carcinoma, Tumor necrosis, Prognosis, Meta-analysis

\section{Background}

Renal cell carcinoma (RCC), the third most common urologic tumor, accounts for $2-3 \%$ of all adult malignancies [1], and its incidence has continuously increased over the past few decades [2]. Although most RCC cases are diagnosed at an early stage, approximately $20 \%$ of patients undergoing curative nephrectomy will subsequently develop metastasis during the follow-up period [3]. Due to the varying efficacy of adjuvant therapies in $\mathrm{RC}$, it is necessary to define more prognostic factors that

\footnotetext{
* Correspondence: jyrmyywb@163.com

'Zhenlei Zha, Wei Qu and Hu Zhao contributed equally to this work. 'Department of Urology, Affiliated Jiang-yin Hospital of the Southeast University Medical College, Jiang-yin 214400, People's Republic of China Full list of author information is available at the end of the article
}

will allow identification of patients at high risk of recurrence who may benefit from such treatment.

Currently, TNM stage classification [4] and the Fuhrman grade system [5] are the most important factors affecting the prognosis of patients with RCC. Additionally, several integrated prognostic models and histologic characteristics have been studied for their prognostic impact, including the American Joint Committee on Cancer (AJCC) staging system [6], International Society of Urologic Pathologists (ISUP) [7] and Mayo Clinic Stage, Size, Grade and Necrosis (SSIGN) Score [8], though these parameters are not entirely reliable. Tumor necrosis (TN) is believed to define regions of severe and chronic hypoxia, and there is renewed interest in using $\mathrm{TN}$ to predict

(c) The Author(s). 2018 Open Access This article is distributed under the terms of the Creative Commons Attribution 4.0 International License (http://creativecommons.org/licenses/by/4.0/), which permits unrestricted use, distribution, and reproduction in any medium, provided you give appropriate credit to the original author(s) and the source, provide a link to the Creative Commons license, and indicate if changes were made. The Creative Commons Public Domain Dedication waiver (http://creativecommons.org/publicdomain/zero/1.0/) applies to the data made available in this article, unless otherwise stated. 
prognosis after tumor resection. However, the prognostic impact of TN in RCC remains controversial, and there is increasing debate on whether TN can provide any additional information beyond grade and stage [9].

Hence, to further clarify the prognostic value of TN in RCC, we performed a systematic review and meta-analysis of the available published literature to evaluate whether the presence of TN has a prognostic impact on cancer-specific survival (CSS), overall survival (OS), recurrence-free survival (RFS) and progression-free-survival (PFS) in RCC patients.

\section{Methods}

\section{Literature search strategy}

According to the PRISMA guidelines [10], a comprehensive literature search was conducted using the electronic databases of PubMed, EMBASE and Web of Science up to April 2018. The MeSH terms and full text terms adopted were as follows: "kidney neoplasms", "renal cell cancer", "renal cell carcinoma", "necrosis", "tumor necrosis", "prognosis", "prognostic outcome", "survival outcome", "oncologic outcome" and their combinations. We also manually searched the reference lists of reviews, meta-analyses, and selected research articles to identify other "gray literature". The language of the publications was restricted to English.

\section{Inclusion and exclusion criteria}

Eligible studies were selected only if they met the following criteria: (i) RCC and TN were pathologically confirmed, with all patients undergoing surgical resection; (ii) the potential prognostic value of $\mathrm{TN}$ for CSS, OS, RFS and PFS were reported; (iii) the authors categorically reported hazard ratios (HRs) and 95\% confidence intervals (95\%CIs), or they could be computed from the given data. Studies were excluded if the following criteria were met: (i) animal models or cancer cell lines were used; (ii) reviews, letters, commentaries, case reports and non-original articles; (iii) $\mathrm{TN}$, clinical features and survival outcome were not analyzed; (iv) lacking sufficient data to acquire HRs and 95\%CIs; (v) not in English. Additionally, when duplicate articles were found, only the most informative and recent article was adopted.

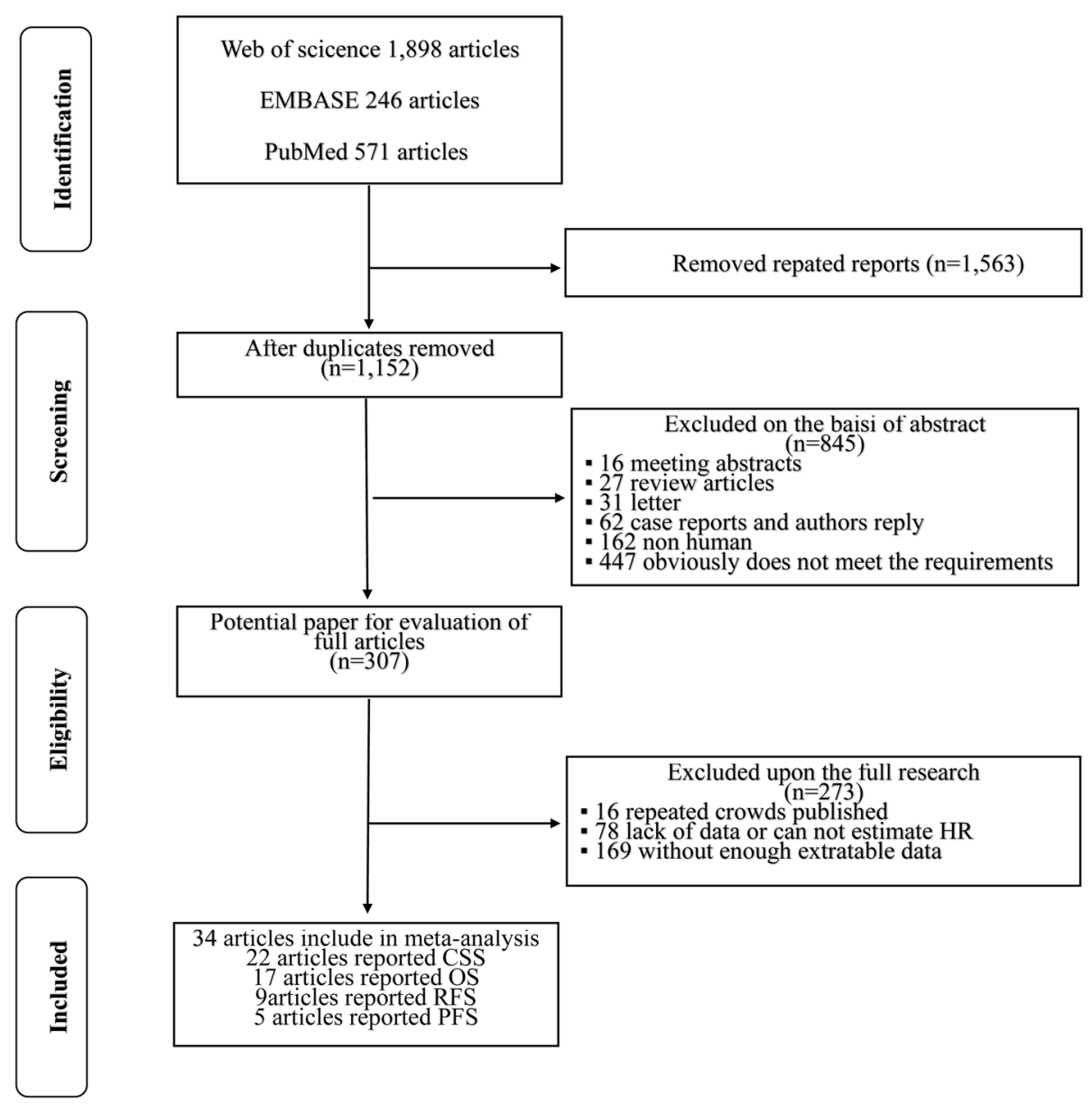

Fig. 1 Diagram of the literature search used in this meta-analysis 


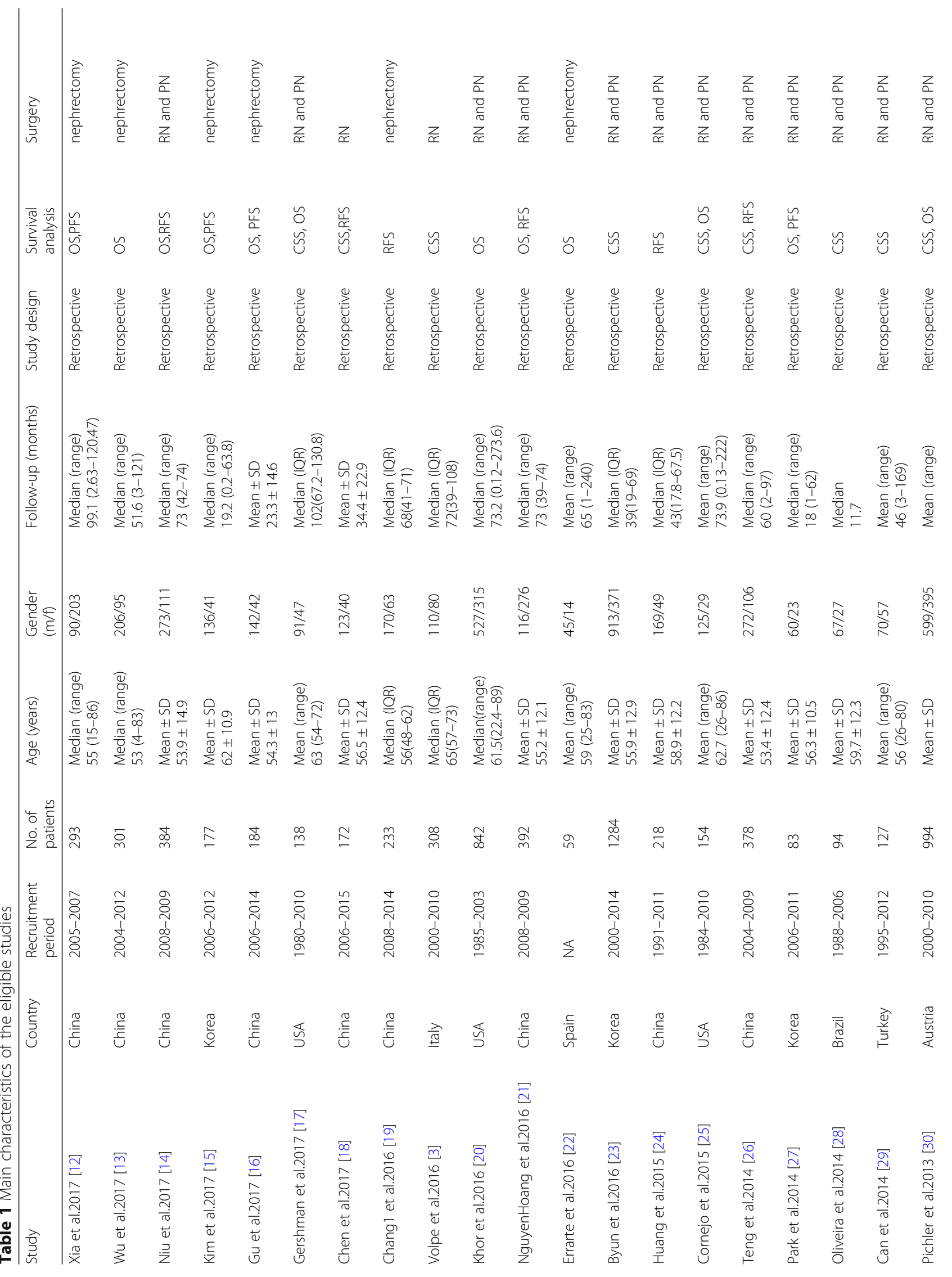




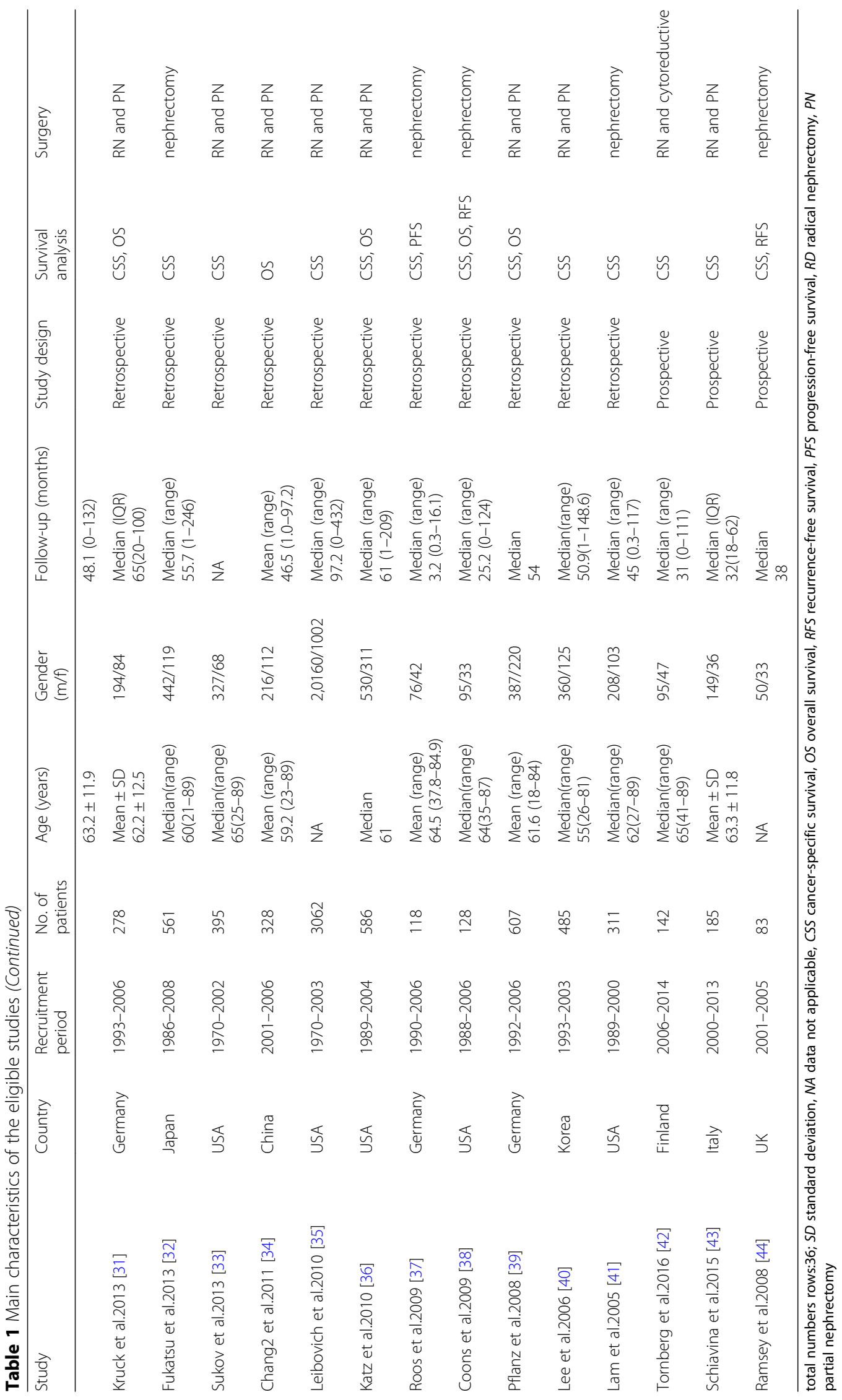




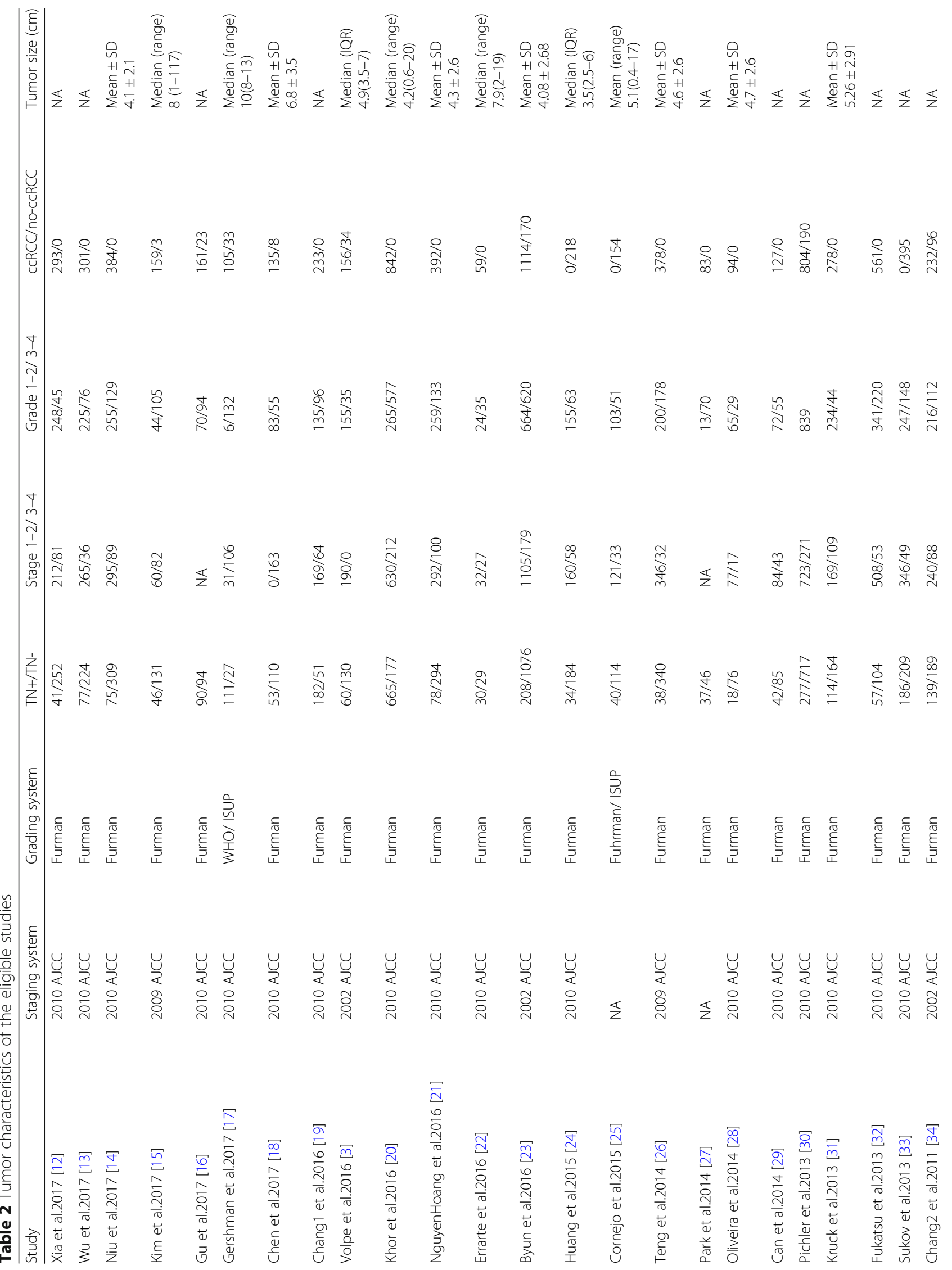




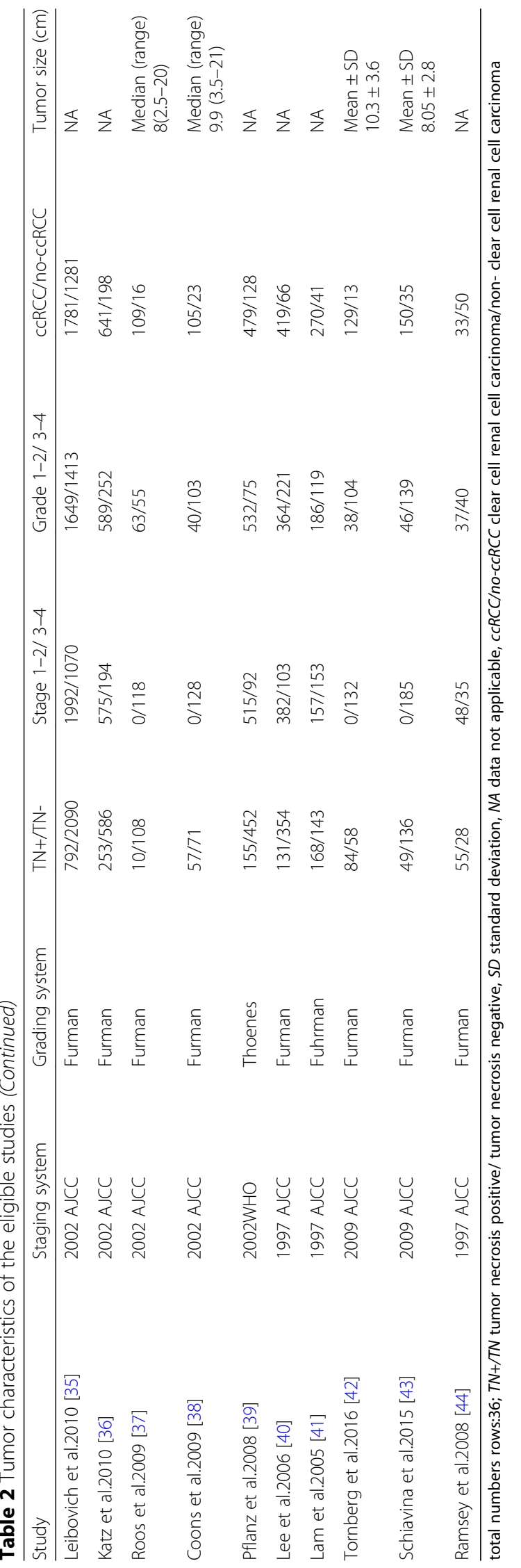




\section{Data extraction and quality assessments}

Two investigators independently extracted data of eligible studies using a standardized form for the following information: author identification, year of publication, country, period of recruitment, study design, age of patients, gender ratio, sample size, follow-up time, study design, interpretation of TN, histology and survival end point. For HRs and 95\% CIs, multivariate analysis data were preferentially adopted. If these data were not available, then univariate analysis of survival outcomes was extracted instead. All discrepancies between the investigators reached a consensus through discussion. The methodological quality of the included cohort studies was assessed using the Newcastle-Ottawa scale (NOS) [11]. Each study was assessed using 8 methodology items in 3 domains with a score ranging from 0 to 9 . High scores indicated high quality, a study with a score $\geq 6$ was regarded as high quality, a score $<6$ was regarded as low quality.

\section{Statistical analysis}

Statistical analyses were performed using Stata 12.0 software (Stat Corp, College Station, TX, USA). Dichotomous variables were calculated using HRs, and pooled HRs with 95\% CI were used to evaluate the association of TN with RCC prognosis (CSS, OS, RFS and PFS). A heterogeneity test of the pooled HR was conducted using a Chi-square-based $Q$ test and Higgins $\boldsymbol{I}^{2}$ statistic. When $\boldsymbol{I}^{2}$ $<50 \%$ or $\mathrm{P}_{\text {heterogeneity }}>0.1$, no obvious heterogeneity existed among the studies, and the fixed-effects (FE) model would be applied; otherwise, the random-effects (RE) model was applied. To obtain a more precise evaluation of heterogeneity, subgroup analysis was performed for CSS, OS and RFS based on geographical region, pathological types, staging system, No. of patients and median follow-up. Publication bias was examined using funnel plots and Egger's linear regression test. Additionally, sensitivity analysis was used to estimate the robustness of


Fig. 2 a Forest plots of studies evaluating the association between TN and CSS outcomes in RCC patients. b Forest plots of studies evaluating the association between TN and OS outcomes in RCC patients. c Forest plots of studies evaluating the association between TN and RFS outcomes in RCC patients. $\mathbf{d}$ Forest plots of studies evaluating the association between TN and PFS outcomes in RCC patients 
Table 3 Summary and subgroup analysis for the eligible studies

\begin{tabular}{|c|c|c|c|c|c|c|}
\hline \multirow{2}{*}{$\begin{array}{l}\text { Analysis } \\
\text { specification }\end{array}$} & \multirow{2}{*}{$\begin{array}{l}\text { No. of } \\
\text { studies }\end{array}$} & \multicolumn{2}{|c|}{ Study heterogeneity } & \multirow{2}{*}{$\begin{array}{l}\text { Effects } \\
\text { model }\end{array}$} & \multirow{2}{*}{$\begin{array}{l}\text { Pooled } \\
\text { HR(95\% Cl) }\end{array}$} & \multirow[t]{2}{*}{$p$-Value } \\
\hline & & $\overline{1^{2}(\%)}$ & $\overline{P_{\text {heterogeneity }}}$ & & & \\
\hline \multicolumn{7}{|l|}{ CSS } \\
\hline Overall & 22 & 76.5 & $<0.001$ & Random & $1.37(1.23,1.53)$ & $<0.001$ \\
\hline \multicolumn{7}{|c|}{ Geographical region } \\
\hline Asian & 7 & 51.7 & 0.053 & Random & $1.34(1.12,1.59)$ & 0.001 \\
\hline Other regions & 15 & 80.8 & $<0.001$ & Random & $1.40(1.22,1.60)$ & $<0.001$ \\
\hline \multicolumn{7}{|l|}{ Pathological types } \\
\hline $\operatorname{ccRCC}$ & 6 & 0 & 0.775 & Fixed & $1.34(1.15,1.55)$ & $<0.001$ \\
\hline Other types & 16 & 81.7 & $<0.001$ & Random & $1.38(1.22,1.58)$ & $<0.001$ \\
\hline \multicolumn{7}{|l|}{ Staging system } \\
\hline 2010 AJCC & 8 & 0 & 0.981 & Fixed & $1.30(1.17,1.44)$ & $<0.001$ \\
\hline Other system & 14 & 82.3 & $<0.001$ & Random & $1.42(1.23,1.64)$ & $<0.001$ \\
\hline \multicolumn{7}{|l|}{ No. of patients } \\
\hline$\geq 300$ & 13 & 82 & $<0.001$ & Random & $1.39(1.21,1.61)$ & $<0.001$ \\
\hline$<300$ & 9 & 15,4 & 0.301 & Fixed & $1.33(1.16,1.51)$ & $<0.001$ \\
\hline \multicolumn{7}{|l|}{ Median follow-up } \\
\hline$\geq 40$ months & 12 & 83.3 & $<0.001$ & Random & $1.36(1.16,1.60)$ & $<0.001$ \\
\hline$<40$ months & 9 & 30.2 & 0.177 & Fixed & $1.33(1.16,1.51)$ & $<0.001$ \\
\hline \multicolumn{7}{|l|}{ OS } \\
\hline Overall & 17 & 57.6 & 0.002 & Random & $1.29(1.20,1.40)$ & $<0.001$ \\
\hline \multicolumn{7}{|c|}{ Geographical region } \\
\hline Asian & 9 & 30.2 & 0.177 & Fixed & $1.38(1.25,1.51)$ & $<0.001$ \\
\hline Other regions & 8 & 58.6 & 0.017 & Random & $1.20(1.09,1.34)$ & $<0.001$ \\
\hline \multicolumn{7}{|l|}{ Pathological types } \\
\hline $\operatorname{ccRCC}$ & 8 & 48.8 & 0.057 & Random & $1.33(1.19,1.49)$ & $<0.001$ \\
\hline Other types & 9 & 62.7 & 0.006 & Random & $1.26(1.13,1.41)$ & $<0.001$ \\
\hline \multicolumn{7}{|l|}{ Staging system } \\
\hline 2010 AJCC & 10 & 63.6 & 0.003 & Random & $1.30(1.17,1.44)$ & $<0.001$ \\
\hline Other system & 7 & 53.1 & 0.046 & Random & $1.30(1.14,1.47)$ & $<0.001$ \\
\hline \multicolumn{7}{|l|}{ No. of patients } \\
\hline$\geq 300$ & 8 & 67.5 & 0.003 & Random & $1.25(1.12,1.39)$ & $<0.001$ \\
\hline$<300$ & 9 & 29.2 & 0.185 & Fixed & $1.35(1.22,1.49)$ & $<0.001$ \\
\hline \multicolumn{7}{|l|}{ Median follow-up } \\
\hline$\geq 40$ months & 13 & 62.6 & 0.001 & Random & $1.27(1.16,1.39)$ & $<0.001$ \\
\hline$<40$ months & 4 & 0 & 0.412 & Fixed & $1.37(1.20,1.56)$ & $<0.001$ \\
\hline \multicolumn{7}{|l|}{ RFS } \\
\hline Overall & 9 & 35.6 & 0.133 & Fixed & $1.55(1.39,1.72)$ & $<0.001$ \\
\hline \multicolumn{7}{|c|}{ Geographical region } \\
\hline Asian & 6 & 42.7 & 0.12 & Fixed & $1.48(1.31,1.66)$ & $<0.001$ \\
\hline Other regions & 3 & 0 & 0.684 & Fixed & $1.87(1.41,2.37)$ & $<0.001$ \\
\hline \multicolumn{7}{|l|}{ Pathological types } \\
\hline cCRCC & 4 & 0 & 0.541 & Fixed & $1.61(1.40,1.86)$ & $<0.001$ \\
\hline Other types & 5 & 57.5 & 0.051 & Random & $1.46(1.25,1.71)$ & $<0.001$ \\
\hline
\end{tabular}

Staging system 
Table 3 Summary and subgroup analysis for the eligible studies (Continued)

\begin{tabular}{|c|c|c|c|c|c|c|}
\hline \multirow{2}{*}{$\begin{array}{l}\text { Analysis } \\
\text { specification }\end{array}$} & \multirow{2}{*}{$\begin{array}{l}\text { No. of } \\
\text { studies }\end{array}$} & \multicolumn{2}{|c|}{ Study heterogeneity } & \multirow{2}{*}{$\begin{array}{l}\text { Effects } \\
\text { model }\end{array}$} & \multirow{2}{*}{$\begin{array}{l}\text { Pooled } \\
\text { HR(95\% CI) }\end{array}$} & \multirow[t]{2}{*}{$p$-Value } \\
\hline & & $\mathrm{P}^{2}(\%)$ & $\overline{P_{\text {heterogeneity }}}$ & & & \\
\hline 2010 AJCC & 5 & 54 & 0.069 & Random & $1.48(1.31,1.69)$ & $<0.001$ \\
\hline Other system & 4 & 0 & 0.483 & Fixed & $1.69(1.40,2.04)$ & $<0.001$ \\
\hline \multicolumn{7}{|l|}{ No. of patients } \\
\hline$\geq 300$ & 4 & 0 & 0.702 & Fixed & $1.57(1.35,1.83)$ & $<0.001$ \\
\hline$<300$ & 5 & 63.4 & 0.027 & Random & $1.52(1.32,1.76)$ & $<0.001$ \\
\hline \multicolumn{7}{|l|}{ Median follow-up } \\
\hline$\geq 40$ months & 6 & 0 & 0.758 & Fixed & $1.62(1.43,1.84)$ & $<0.001$ \\
\hline$<40$ months & 3 & 75.3 & 0.018 & Random & $1.39(1.16,1.68)$ & 0.001 \\
\hline \multicolumn{7}{|l|}{ PFS } \\
\hline Overall & 5 & 32.9 & 0.202 & Fixed & $1.31(1.17,1.46)$ & $<0.001$ \\
\hline \multicolumn{7}{|l|}{ Pathological types } \\
\hline $\mathrm{cCRCC}$ & 2 & 67.8 & 0.078 & Random & $1.44(1.20,1.71)$ & $<0.001$ \\
\hline Other types & 3 & 0 & 0.6 & Fixed & $1.23(1.07,1.41)$ & 0.004 \\
\hline \multicolumn{7}{|l|}{ Staging system } \\
\hline 2010 AJCC & 2 & 76.3 & 0.04 & Random & $1.35(1.18,1.54)$ & $<0.001$ \\
\hline Other system & 3 & 0 & 0.582 & Fixed & $1.22(1.01,1.48)$ & 0.036 \\
\hline
\end{tabular}

the results via sequential omission of individual studies. A $p$ value of $<0.05$ was considered to indicate significance.

\section{Results}

\section{Search and eligible studies}

A diagram of the selection process is shown in Fig. 1. According to the search strategy, 2715 articles were retrieved from the electronic databases. By excluding 1563 duplicate reports, 1152 articles were considered potentially relevant based on screening of the titles and abstracts. The remaining articles were further excluded upon full-text review for several reasons, such as a lack of sufficient data to estimate HRs or duplicate publication in repeated cohorts. Ultimately, 34 studies [3, 12-44] that focused on the association between RCC and TN were included for meta-analysis. The outcomes were CSS in 22 studies, OS in 17 studies, RFS in 9 studies and PFS in 5 studies.

\section{Characteristics of the included studies}

The main characteristics of the 34 eligible studies are listed in Table 1. All of the studies were published between 2005 and 2017, with a mean duration of follow-up varying from 11.7 to 102 months. The present meta-analysis was based on a total sample size of 14,084 patients, ranging from 59 to 3062 patients. The NOS was applied to assess the methodological quality of the included studies, and the results showed that all studies were of high quality (Additional file 1: Table S1). All of the included studies were based on data for retrospective analyses of survival (CSS, OS, RFS, PFS). The characteristics, including tumor features and pathologic outcomes, are summarized in Table 2. TN was detected in $31.6 \%(4452 / 14,084)$ of the pathological specimens from the included patients. A total of 13 of the included studies were limited to clear cell renal cell carcinoma (ccRCC), whereas 21 studies involved various tumor types, including ccRCC, papillary renal cell carcinoma, chromophobe renal cell carcinoma and unclassified tumor.

\section{Prognostic value of TN for survival outcome}

The present meta-analysis demonstrated that TN in RCC is associated with poor CSS (RE HR $=1.37,95 \%$ CI: $1.23-1.53$, $p<0.001, \boldsymbol{I}^{2}=76.5 \%, \mathrm{P}_{\text {heterogeneity }}<0.001$; Fig. 2a), OS (RE $\mathrm{HR}=1.29,95 \%$ CI: $1.20-1.40, p<0.001, \boldsymbol{I}^{2}=57.6 \%, \mathrm{P}_{\text {hetero- }}$ geneity $=0.02$; Fig. $2 \mathrm{~b}$ ), RFS (FE $\mathrm{HR}=1.55,95 \% \mathrm{CI}: 1.39-1.72$, $p<0.001, \mathbf{I}^{2}=35.6 \%, \mathrm{P}_{\text {heterogeneity }}=0.133$; Fig. 2c) and PFS (FE HR $=1.31$, 95\% CI: $1.17-1.46, p<0.001, \boldsymbol{I}^{2}=32.9 \%$, $\mathrm{P}_{\text {heterogeneity }}=0.202$; Fig. 2d). To explore the source of heterogeneity for CSS, OS and RFS, subgroup analysis was conducted according to geographical region (Asia vs. other regions), pathological type (ccRCC vs. other types), staging system (2010 AJCC vs. other system), No. of patients ( $\geq$ 300 vs. $<300)$ and median follow-up $(\geq 40$ months vs. $<$ 40 months). The results of this subgroup analysis again suggested that TN is a prognostic factor, despite heterogeneity among some groups (Table 3). Notably, heterogeneity for CSS, OS and RFS was significantly decreased in some models, such as geographical region in Asia, ccRCC pathological type, 2010 AJCC staging system and $\geq 300$ cases. 


\section{Sensitivity analyses and publication bias}

In sensitivity analysis excluding one study at a time, the pooled HR for CSS ranged from 1.29 (95\% CI: 1.19-1.39) to 1.37 (95\% CI: 1.22-1.54) (Additional file 2: Figure S1). Similarly, the pooled HR for OS ranged from 1.27 (95\% CI: $1.17-1.37$ ) to 1.31 (95\% CI: $1.21-1.42)$ (Additional file 3: Figure S2), that for RFS from 1.52 (95\% CI:1.32-1.76) to 1.66 (95\% CI: 1.47-1.86) (Additional file 4: Figure S3), and that for PFS from 1.21 (95\% CI:1.07-1.38) to 1.35 (95\% CI: 1.12-1.63) (Additional file 5: Figure S4). These results indicate that the findings were reliable and robust. Although no statistical evidence of publication bias was observed for RFS $(p-$ Egger $=0.135$, Fig. 3c $)$ and PFS (p-Egger $=0.932$, Fig. 3d), publication bias was observed for CSS (p-Egger $=0.006$, Fig. 3a) and OS (p-Egger = 0.001, Fig. 3b).

\section{Discussion}

RCC is the most common solid lesion of the kidney, and more than $40 \%$ of patients die from this type of cancer [2]. Despite significant improvements in systemic therapy for
RCC, the prognosis of patients with RCC and treatment response rates have not substantially increased [17, 42, 44]. Although several pathologic parameters, including lymphatic vessel invasion [45], tumor fat invasion [26] and primary tumor size [43], provide independent prognostic information, the likely outcome for an individual patient remains uncertain. The TNM stage and Fuhrman grade system are the most widely used approaches for RCC; however, there have been many recent suggestions for modifications based on survival trends in large case series [46]. Additionally, RCC is a highly heterogeneous disease with different clinical presentations and characteristics that remain somewhat unpredictable [47]. Therefore, it is essential to optimize the treatment and prognosis of RCC and to provide better counseling for each RCC patient.

The presence of TN in pathologic specimens may reflect the tumor biology and may also provide additional useful prognostic information. As TN results from rapid tumor proliferation and consequent outgrowth of the blood supply [41], histologic TN has been proposed to

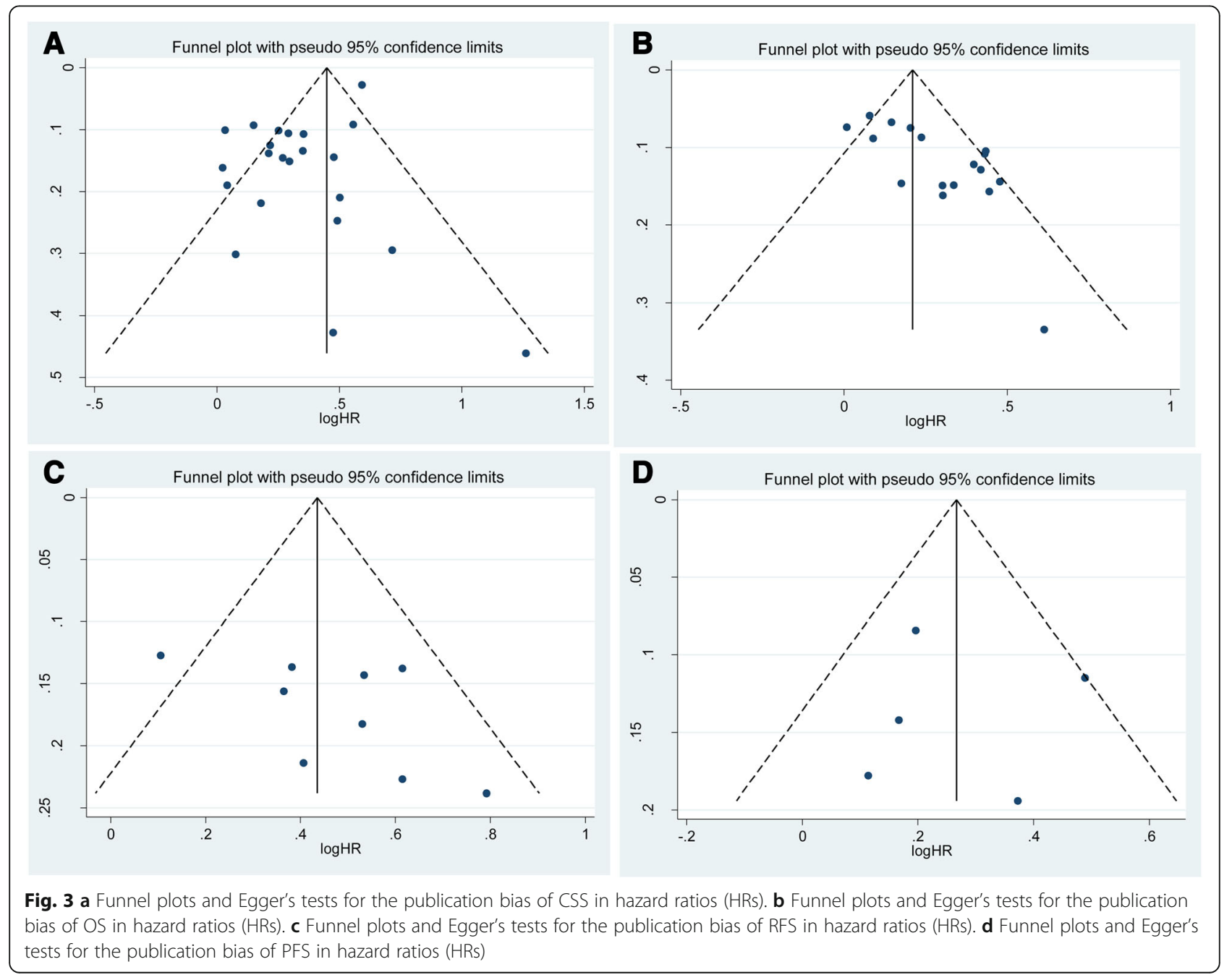


be a sign of tumor aggressiveness that generally leads to poor clinical outcomes [48]. Previous studies have investigated the association of TN with various solid tumors, including breast cancer [49], colorectal cancer [50] and lung cancer [51]. Indeed, there is renewed interest in using TN, which can be assessed in every routine pathological examination without additional costs, to more accurately predict the clinical outcome of RCC. For example, Khor et al. [20] and Ito et al. [48] reported that TN is strongly associated with poor survival and should serve as an independent prognostic factor for patients with RCC. Nonetheless, some studies have shown that the presence of any TN is a negative predictor of survival in RCC $[52,53]$.

To our knowledge, the present study is the first meta-analysis on the association between TN and clinical outcomes of different types of RCC. In this analysis, 14,084 RCC patients were included from 34 cohort studies, and TN was detected in $31.6 \%$ of 4452 RCC patients. Robust evidence obtained from sensitivity analysis demonstrated that the presence of TN was associated with poor outcomes in terms of CSS (HR $=1.37, p<0.001)$, OS $(\mathrm{HR}=1.29, p<0.001)$, RFS $(\mathrm{HR}=1.55, p<0.001)$ and PFS $(\mathrm{HR}=1.31, p<0.001)$ in patients with RCC. These findings were consistently independent of geographical region, pathological type, staging system, No. of patients and median follow-up. Although there was no evidence of heterogeneity in terms of CSS or PFS, significant heterogeneity was detected in analyses of OS and RFS models. To further explore the source of heterogeneity in OS and RFS, subgroup analysis was conducted, and the data showed that significant variations were reduced in OS and RFS within some items.

Notably, the present study has several limitations. First, all the included studies were retrospective cohort studies, and data extracted from those studies may have led to inherent potential bias. Second, the criteria for determining the presence of $\mathrm{TN}$ in a pathologic specimen were inconsistent in the included studies, which may contribute to heterogeneity. Thus, rigorous morphological criteria should be used to standardize the diagnosis of TN. Third, we only included published studies written in English, and the lack of "gray literature" may cause selection bias. Fourth, substantial heterogeneity was observed in meta-analysis of CSS and OS, and although we selected the RE model according to heterogeneity, this diversity remained. Using subgroup analysis, we propose that the heterogeneity likely reflected differences in factors, such as patient and tumor characteristics. Fifth, a statistical publication bias was observed for CSS and OS according to Egger's test. In general, studies with negative results tend not to be submitted or published; therefore, a certain degree of publication bias was observed in the present study. Finally, it should be noted that factors, including age, sex, histology type and surgical method, that may affect survival outcomes were adequately controlled.

Nevertheless, the present study has several key strengths. First, the meta-analysis included 34 studies with large sample sizes, with the ability to detect more stable associations between TN and clinical outcomes of RCC patients. Second, with strict inclusion and exclusion criteria, we extracted available data from relevant studies. Furthermore, through subgroup and sensitivity analyses, the results were reliable and robust. Therefore, TN determination, with excellent accessibility and low costs, warrants wider application in patients with RCC for risk stratification and decision-making of individualized treatment.

\section{Conclusions}

In conclusion, the results of the present meta-analysis demonstrate that TN in histopathology is associated with poor CSS, OS, RFS and PFS in patients with RCC. Due to the limitations of the present study, large-scale, multicenter prospective studies with long-term follow-up are needed to verify these results.

\section{Additional files}

\section{Additional file 1: Table S1. Quality assessment of cohort studies included in this meta- analysis. (DOCX $15 \mathrm{~kb}$ )}

Additional file 2: Figure S1. Sensitivity analysis of the association between TN and CSS outcomes in RCC patients. (TIF $302 \mathrm{~kb}$ )

Additional file 3: Figure S2. Sensitivity analysis of the association between TN and OS outcomes in RCC patients. (TIF 255 kb)

Additional file 4: Figure S3. Sensitivity analysis of the association between TN and RFS outcomes in RCC patients. (TIF $157 \mathrm{~kb}$ )

Additional file 5: Figure S4. Sensitivity analysis of the association between TN and PFS outcomes in RCC patients. (TIF $115 \mathrm{~kb}$ )

\section{Abbreviations}

AJCC: American Joint Committee on Cancer; ccRCC: Clear cell renal cell carcinoma; Cls: Corresponding 95\% confidence intervals; CSS: Cancer-specific survival; FE: Fixed-effects; HRs: Hazard ratios; ISUP: International Society of Urologic Pathologists; NOS: Newcastle Ottawa scale; OS: Overall survival; PFS: Progression-free-survival; PRISMA: Preferred Reporting Items for Systematic Reviews and Meta-Analyses; RCC: Renal cell carcinoma; RE: Random-effects; RFS: Recurrence-free survival; SSIGN: Mayo Clinic Stage, Size, Grade and Necrosis; TN: Tumor necrosis

\section{Availability of data and materials}

All data generated or analyzed during the present study are included in this published article (and its additional files).

\section{Authors' contributions}

$\mathrm{LJZ}$ and BW designed the research. ZLZ, WQ and HZ performed the literature search. JY and YJF analyzed the data and interpreted the results. LJZ drafted the manuscript. All authors approved the final manuscript.

Ethics approval and consent to participate Not applicable.

Consent for publication Not applicable. 


\section{Competing interests}

The authors declare that they have no competing interests.

\section{Publisher's Note}

Springer Nature remains neutral with regard to jurisdictional claims in published maps and institutional affiliations.

\section{Author details}

'Department of Urology, Affiliated Jiang-yin Hospital of the Southeast University Medical College, Jiang-yin 214400, People's Republic of China. 2Department of Pharmacy, Affiliated Jiang-yin Hospital of the Southeast University Medical College, Jiang-yin 214400, People's Republic of China.

\section{Received: 2 April 2018 Accepted: 23 August 2018}

\section{Published online: 03 September 2018}

\section{References}

1. Flum AS, Hamoui N, Said MA, Yang XJ, Casalino DD, McGuire BB, Perry KT, Nadler RB. Update on the diagnosis and Management of Renal Angiomyolipoma. J Urol. 2016;195(4 Pt 1):834-46.

2. Siegel RL, Miller KD, Jemal A. Cancer statistics, 2017. CA Cancer J Clin. 2017; 67(1):7-30

3. Volpe A, Bollito E, Bozzola C, Di Domenico A, Bertolo R, Zegna L, Duregon E, Boldorini R, Porpiglia F, Terrone C. Classification of histologic patterns of Pseudocapsular invasion in organ-confined renal cell carcinoma. Clinical genitourinary cancer. 2016;14(1):69-75.

4. May M, Surcel C, Capitanio U, Dell'Oglio P, Klatte T, Shariat S, Ecke T, Wolff I, Vergho D, Wagener N, et al. Prognostic and discriminative power of the 7th TNM classification for patients with surgically treated papillary renal cell carcinoma: results of a multi-institutional validation study (CORONA subtype project). Scandinavian journal of urology. 2017:1-8

5. Smith ZL, Pietzak EJ, Meise CK, Van Arsdalen K, Wein AJ, Malkowicz SB, Guzzo TJ. Simplification of the Fuhrman grading system for renal cell carcinoma. Can J Urol. 2015:22(6):8069-73.

6. Martinez-Salamanca JI, Huang WC, Millan I, Bertini R, Bianco FJ, Carballido JA, Ciancio G, Hernandez C, Herranz F, Haferkamp A, et al. Prognostic impact of the 2009 UICC/AJCC TNM staging system for renal cell carcinoma with venous extension. Eur Urol. 2011:59(1):120-7.

7. Moch $\mathrm{H}$. The WHO/ISUP grading system for renal carcinoma. Pathologe. 2016:37(4):355-60.

8. Zigeuner R, Hutterer G, Chromecki T, Imamovic A, Kampel-Kettner K, Rehak P, Langner C, Pummer K. External validation of the Mayo Clinic stage, size, grade, and necrosis (SSIGN) score for clear-cell renal cell carcinoma in a single European Centre applying routine pathology. Eur Urol. 2010;57(1):102-9.

9. Khor LY, Dhakal HP, Jia X, Reynolds JP, McKenney JK, Rini BI, Magi-Galluzzi C, Przybycin CG. Tumor necrosis adds Prognostically significant information to grade in clear cell renal cell carcinoma: a study of 842 consecutive cases from a single institution. Am J Surg Pathol. 2016:40(9):1224-31.

10. Liberati A, Altman DG, Tetzlaff J, Mulrow C, Gotzsche PC, loannidis JP, Clarke M, Devereaux PJ, Kleijnen J, Moher D. The PRISMA statement for reporting systematic reviews and meta-analyses of studies that evaluate health care interventions: explanation and elaboration. J Clin Epidemiol. 2009;62(10):e1-34

11. Stang A. Critical evaluation of the Newcastle-Ottawa scale for the assessment of the quality of nonrandomized studies in meta-analyses. Eur J Epidemiol. 2010;25(9):603-5.

12. Xia Y, Liu L, Bai $\mathrm{O}$, Long $\mathrm{O}$, Wang J, Xi W, Xu J, Guo J. Prognostic value of copper transporter 1 expression in patients with clear cell renal cell carcinoma. Oncol Lett. 2017;14(5):5791-800.

13. Wu CY, Huo JP, Zhang XK, Zhang YJ, Hu WM, Yang P, Lu JB, Zhang ZL, Cao $Y$. Loss of CD15 expression in clear cell renal cell carcinoma is correlated with worse prognosis in Chinese patients. Jpn J Clin Oncol. 2017;47(12):1182-8.

14. Niu T: Increased expression of MUC3A is associated with poor prognosis in localized clear-cell renal cell carcinoma. 2017.

15. Kim SH, Kim S, Nam BH, Lee SE, Kim CS, Seo IY, Kim TN, Hong SH, Kwon TG, Seo SI, et al. Primary tumor characteristics are important prognostic factors for Sorafenib-treated patients with metastatic renal cell carcinoma: a retrospective multicenter study. Biomed Res Int. 2017;2017:9215930.
16. Gu L, Li H, Wang H, Ma X, Wang L, Chen L, Zhao W, Zhang Y, Zhang X. Presence of sarcomatoid differentiation as a prognostic indicator for survival in surgically treated metastatic renal cell carcinoma. J Cancer Res Clin Oncol. 2017;143(3):499-508.

17. Gershman B, Moreira DM, Thompson RH, Boorjian SA, Lohse CM, Costello BA, Cheville JC, Leibovich BC. Renal cell carcinoma with isolated lymph node involvement: long-term natural history and predictors of oncologic outcomes following surgical resection. Eur Urol. 2017;

18. Chen L, Ma X, Li H, Gu L, Li X, Gao Y, Xie Y, Zhang X. Influence of tumor size on oncological outcomes of pathological T3aNOM0 renal cell carcinoma treated by radical nephrectomy. PLoS One. 2017;12(3):e0173953.

19. Chang Y, Xu L, Zhou L, Fu Q, Liu Z, Yang Y, Lin Z, Xu J. Granulocyte macrophage colony-stimulating factor predicts postoperative recurrence of clear-cell renal cell carcinoma. Oncotarget. 2016;7(17):24527-36.

20. Li-Yan Khor M, Hari P. Dhakal, MD Xuefei Jia MS, Jordan P. Reynolds M, Jesse K. McKenney M, Brian I. Rini MD, Cristi namagi-Galluzzi M, and Christopher G. Przybycin M: tumor necrosis adds Prognostically SignificantInformation to grade in clear cell renal cell carcinoma a study of 842 consecutive cases from a single institution. 2016.

21. NguyenHoang S, Liu Y, Xu L, Chang Y, Zhou L, Liu Z, Lin Z, Xu J. high mucin-7 expression is an independent predictor of adverse clinical outcomes in patients with clear-cell renal cell carcinoma. Tumour Biol. 2016;37(11):15193-201.

22. Errarte P, Guarch R, Pulido R, Blanco L, Nunes-Xavier CE, Beitia M, Gil J, Angulo JC, Lopez JI, Larrinaga G. The expression of fibroblast activation protein in clear cell renal cell carcinomas is associated with synchronous lymph node metastases. PLoS One. 2016;11(12):e0169105.

23. Byun SS, Hwang EC, Kang SH, Hong SH, Chung J, Kwon TG, Kim HH, Kwak C, Kim YJ, Lee WK. Prognostic significance of preoperative neutrophil-tolymphocyte ratio in nonmetastatic renal cell carcinoma: a large, multicenter cohort analysis. Biomed Res Int. 2016;2016:5634148.

24. Huang J, Dahl DM, Dong L, Liu Q, Cornejo K, Wang Q, Wu S, Feldman AS, Huang Y, Xue W, et al. Preoperative neutrophil-to-lymphocyte ratio and Neutrophilia are independent predictors of recurrence in patients with localized papillary renal cell carcinoma. Biomed Res Int. 2015;2015:891045.

25. Cornejo KM, Dong F, Zhou AG, Wu C-L, Young RH, Braaten K, Sadow PM, Nielsen GP, Oliva E. Papillary renal cell carcinoma: correlation of tumor grade and histologic characteristics with clinical outcome. Hum Pathol. 2015:46(10):1411-7.

26. Teng J, Gao Y, Chen M, Wang K, Cui X, Liu Y, Xu D. prognostic value of clinical and pathological factors for surgically treated localized clear cell renal cell carcinoma. Chin Med J. 2014;127(9):1640-4.

27. Park JY, Lee JL, Baek S, Eo SH, Go H, Ro JY, Cho YM. Sarcomatoid features, necrosis, and grade are prognostic factors in metastatic clear cell renal cell carcinoma with vascular endothelial growth factor-targeted therapy. Hum Pathol. 2014;45(7):1437-44

28. de Oliveira D, Dall'Oglio MF, Reis ST, Zerati M, Souza IC, Leite KR, Srougi M. Chromosome $9 p$ deletions are an independent predictor of tumor progression following nephrectomy in patients with localized clear cell renal cell carcinoma. Urol Oncol. 2014;32(5):601-6.

29. Can C, Acikalin MF, Ozen A, Dundar E. Prognostic impact of intratumoral Creactive protein expression in patients with clear cell renal cell carcinoma. Urol Int. 2014:92(3):270-5.

30. Pichler M, Hutterer GC, Stojakovic T, Mannweiler S, Pummer K, Zigeuner R. High plasma fibrinogen level represents an independent negative prognostic factor regarding cancer-specific, metastasis-free, as well as overall survival in a European cohort of non-metastatic renal cell carcinoma patients. Br J Cancer. 2013;109(5):1123-9.

31. Kruck S, Eyrich C, Scharpf M, Sievert KD, Fend F, Stenzl A, Bedke J. Impact of an altered Wnt1/beta-catenin expression on clinicopathology and prognosis in clear cell renal cell carcinoma. Int J Mol Sci. 2013;14(6):10944-57.

32. Fukatsu A, Tsuzuki T, Sassa N, Nishikimi T, Kimura T, Majima T, Yoshino $Y_{1}$ Hattori R, Gotoh M. Growth pattern, an important pathologic prognostic parameter for clear cell renal cell carcinoma. Am J Clin Pathol. 2013;140(4):500-5.

33. Sukov WR, Lohse CM, Leibovich BC, Thompson RH, Cheville JC. Clinical and pathological features associated with prognosis in patients with papillary renal cell carcinoma. J Urol. 2012;187(1):54-9.

34. Chang YH, Chuang CK, Pang ST, Wu CT, Chuang KL, Chuang HC, Liao SK. Prognostic value of TNM stage and tumor necrosis for renal cell carcinoma. Kaohsiung J Med Sci. 2011;27(2):59-63. 
35. Leibovich BC, Lohse CM, Crispen PL, Boorjian SA, Thompson RH, Blute ML, Cheville JC. Histological subtype is an independent predictor of outcome for patients with renal cell carcinoma. J Urol. 2010;183(4):1309-15.

36. Katz MD, Serrano MF, Grubb RL 3rd, Skolarus TA, Gao F, Humphrey PA, Kibel AS. Percent microscopic tumor necrosis and survival after curative surgery for renal cell carcinoma. J Urol. 2010;183(3):909-14.

37. Roos FC, Weirich J, Victor A, Elsasser A, Brenner W, Biesterfeld S, Hampel C, Thuroff JW. Impact of several histopathological prognosticators and local tumour extension on oncological outcome in pT3b/c NOMO renal cell carcinoma. BJU Int. 2009;104(4):461-9.

38. Coons BJ, Stec AA, Stratton KL, Chang SS, Cookson MS, Duke Herrell S, Smith JA Jr, Clark PE. Prognostic factors in T3b renal cell carcinoma. World J Urol. 2009;27(1):75-9.

39. Pflanz S, Brookman-Amissah S, Roigas J, Kendel F, Hoschke B, May M. Impact of macroscopic tumour necrosis to predict survival of patients with surgically resected renal cell carcinoma. Scand J Urol Nephrol. 2008;42(6):507-13.

40. Lee SE, Byun SS, Oh JK, Lee SC, Chang IH, Choe G, Hong SK. Significance of macroscopic tumor necrosis as a prognostic indicator for renal cell carcinoma. J Urol. 2006;176(4 Pt 1):1332-7. discussion 1337-1338

41. Lam JS, Shvarts O, Said JW, Pantuck AJ, Seligson DB, Aldridge ME, Bui MH, Liu X, Horvath S, Figlin RA, et al. Clinicopathologic and molecular correlations of necrosis in the primary tumor of patients with renal cell carcinoma. Cancer. 2005;103(12):2517-25.

42. Tornberg SV, Nisen H, Visapaa H, Kilpelainen TP, Jarvinen R, Mirtti T, Kantonen I, Simpanen J, Bono P, Taari K, et al. Outcome of surgery for patients with renal cell carcinoma and tumour thrombus in the era of modern targeted therapy. Scand j urol. 2016;50(5):380-6.

43. Schiavina R, Borghesi M, Chessa F, Dababneh H, Bianchi L, Della Mora L, Del Prete C, Longhi B, Rizzi S, Fiorentino M, et al. The prognostic impact of tumor size on Cancer-specific and overall survival among patients with pathologic T3a renal cell carcinoma. Clin genitourin cancer. 2015;13(4):e235-41.

44. Ramsey S, Lamb GW, Aitchison M, McMillan DC. Prospective study of the relationship between the systemic inflammatory response, prognostic scoring systems and relapse-free and cancer-specific survival in patients undergoing potentially curative resection for renal cancer. BJU Int. 2008; 101(8):959-63.

45. Belsante M, Darwish O, Youssef R, Bagrodia A, Kapur P, Sagalowsky Al, Lotan $Y$, Margulis V: Lymphovascular invasion in clear cell renal cell carcinoma-association with disease-free and cancer-specific survival. Urol Oncol 2014, 32(1):30 e23-38.

46. Zhu Y, Xu L, An H, Liu W, Wang Z, Xu J. p21-activated kinase 1 predicts recurrence and survival in patients with non-metastatic clear cell renal cell carcinoma. Int J Urol. 2015;22(5):447-53.

47. Costa WH, Rocha RM, Cunha IW, Fonseca FP, Guimaraes GC, Zequi Sde C CD133 immunohistochemical expression predicts progression and cancerrelated death in renal cell carcinoma. World J Urol. 2012;30(4):553-8.

48. Ito K, Seguchi K, Shimazaki H, Takahashi E, Tasaki S, Kuroda K, Sato A, Asakuma J, Horiguchi A, Asano T. Tumor necrosis is a strong predictor for recurrence in patients with pathological T1a renal cell carcinoma. Oncol Lett. 2015:9(1):125-30.

49. Coulson R, Liew SH, Connelly AA, Yee NS, Deb S, Kumar B, Vargas AC, O'Toole SA, Parslow AC, Poh A, et al. The angiotensin receptor blocker, losartan, inhibits mammary tumor development and progression to invasive carcinoma. Oncotarget. 2017:8(12):18640-56.

50. Vayrynen SA, Vayrynen JP, Klintrup K, Makela J, Karttunen TJ, Tuomisto A Makinen MJ. Clinical impact and network of determinants of tumour necrosis in colorectal cancer. Br J Cancer. 2016;114(12):1334-42.

51. Wu CF, Fu JY, Yeh CJ, Liu YH, Hsieh MJ, Wu YC, Wu CY, Tsai YH, Chou WC Recurrence risk factors analysis for stage I non-small cell lung Cancer. Medicine. 2015;94(32):e1337.

52. Chen Z, Shao Y, Yao H, Zhuang Q, Wang K, Xing Z, Xu X, He X, Xu R. Preoperative albumin to globulin ratio predicts survival in clear cell renal cell carcinoma patients. Oncotarget. 2017;

53. Klatte T, Said JW, de Martino M, Larochelle J, Shuch B, Rao JY, Thomas GV, Kabbinavar FF, Belldegrun AS, Pantuck AJ. Presence of tumor necrosis is not a significant predictor of survival in clear cell renal cell carcinoma: higher prognostic accuracy of extent based rather than presence/absence classification. J Urol. 2009:181(4):1558-64. discussion 1563-1554

\section{Ready to submit your research? Choose BMC and benefit from:}

- fast, convenient online submission

- thorough peer review by experienced researchers in your field

- rapid publication on acceptance

- support for research data, including large and complex data types

- gold Open Access which fosters wider collaboration and increased citations

- maximum visibility for your research: over $100 \mathrm{M}$ website views per year

At BMC, research is always in progress.

Learn more biomedcentral.com/submissions 